\title{
ANALYZING POTENTIAL OF THE ASSASSINS CREED GAME ON HISTORY LEARNING FOR MILLENIAL IN $21^{\text {st }}$ CENTURY EDUCATION
}

\author{
Jonathan Hamonangan Putra Manurung, Moses Glorino Rumambo Pandin \\ Faculty of Humanities, Airlangga University \\ jonathan.hamonangan.putra.2020@fib.unair.ac.id, moses.glorino@ fib.unair.ac.id
}

\begin{abstract}
History is a part of social science. In history, we can study the various events that occurred in the past that can determine what happened in the future. With this historical knowledge, we can find out the origin of these events in the past through various sources such as books, relics, etc. [R1] However, in the 21 st-century history lessons are starting to be abandoned by the current generation because of the ongoing technological advances. Even though studying history is very important as a provision for carrying out life in the future. Therefore, by taking advantage of these technological advances, we can use the game Assassin's Creed which is booming lately as a way to increase interest in learning history. The purpose of writing this paper is to explain the benefits of the game Assassin's Creed as a medium to increase interest in learning history so that in this game the player not only knows the characters, the time, and the mission but also knows the storyline of this game because it is related to events that have already occurred. To achieve this goal, the article focuses on several questions about historical learning in the present and the use of one of the games to increase interest in learning. The research method used is a literature review that performs data processing and sorting according to the discussion topics discussed by the author. The data is in the form of 20 journal articles with a span of years from 2019-2021 and website 2 trusted sites. The results of this study are in the form of an explanation of historical learning in the 21st century and the game Assassin's Creed with several series that have different synopses but have links to historical events. Thus, technological advances need to be utilized positively through the use of games as a means of increasing interest in learning history.
\end{abstract}

Keywords: games, historical science, technological progress

\section{INTRODUCTION}

History is a science that is inseparable from human life because history itself explains the past and is certainly very influential for human life in the future. So it is very important for us, especially the present generation, to study history by following the developments that are happening at this time. Studying history itself allows us to think critically in understanding everything, especially about the events that are around us, then we can make past events material or policy for the future. Of course, seeing technological developments at this time will make all the information needed faster, but this can affect education, one of which is history learning (5). The generation at this time is starting to leave history lessons because they think history is less interesting and boring, even though studying history is important because from history itself we can know about past events and can be used as learning for the 
future. Of course it can't be left alone because history is very important to study so there needs to be a solution to improve again in studying history (13).

The development of this technology, if used positively, will be useful in finding information and making it easier to understand lessons. There are many alternatives for students to help them in learning, one of which is games. Indeed, through the game, most people think it will make students lazy to learn, but games can also function as knowledge because the contents of the game have values that can be learned by players to broaden their horizons. Here the author takes one of the games, namely Assassin's Creed because the game has a story that matches the facts in history, and this will be very useful for players who are curious about history (7)(4). Therefore, the focus of this article is to answer questions about the form of history learning in the 21 st century which is starting to be abandoned by the current generation so that efforts need to be made by utilizing the Assassin's Creed game as a solution to increase interest in learning history in the 21 st century.

\section{METHOD}

The method used by the authors in this article is the literature review. A literature review is a basic review used by the author is conducting further research following the topic of discussion in depth. This literature review contains several theories and research materials that form the basis for researching according to the topic of discussion. From the research material, the author will process and search for various data and related information that explain the problems discussed by the author, so that the results obtained in this study can be proven to be true (24).

The data collection selection technique refers to the discussion in the form of history learning in the 21st century and the use of the Assassin's Creed game in increasing interest in learning history. The technique used is literature study. Based on the book " Metode Penelitian Kepustakaan" on page 3, library research is a series of activities related to methods of collecting data, reading, and recording research materials. Then on pages 12 and 16 explain that the literature study consists of 2 kinds, namely: (a) Literature study which means the researcher collects some data from journals and (b) Other sources, one of which is Internet searching, which means researchers are looking for data from trusted websites Journal articles are obtained from Google Scholar, while other internet sources are obtained from the official website of the Assassin's Creed game. The search for journal articles and internet sources was obtained according to what was discussed, namely the form of history learning and its objectives and an explanation of the synopsis of the game to its relation to history learning. The 
use of journal articles and internet sources is a reference for this research. The journal articles contain explanations from several previous experts so that there is no doubt about their contents, while internet sources are obtained from trusted websites such as the Assassin's Creed Official Website, where on the web there is in-depth information on the Assassin's Creed game (24).

The data analysis technique is carried out by connecting the synopsis of the Assassin's Creed game to current history learning which is used to find out the benefits of the game on understanding history learning which is an important lesson to learn. The data analysis technique is divided into three stages, namely: a) Data reduction, which means that researchers carry out the process of selecting and centralizing data, b) Presentation of data which means that the researcher presents the data that has been reduced in the form of a brief description or table, and c) Drawing conclusions which means the researcher draws conclusions from the data that has been presented in the form of sentences (23).

The studu applied these stages as a technique in research such as data processing, the process is including: a) Data reduction, which means that researchers do sorting and processing according to a predetermined discussion, namely the form of history learning in the $21 \mathrm{st}$ century and has a relationship with the Assassin's Creed game synopsis, b) Presentation of data which means the researcher provides data in the form of a summary table of results in the appendix and provides several reviews regarding the relationship between history learning in the 21 st century and the synopsis of the Assassin's Creed game, and c) Drawing conclusions, which means that researchers connect history learning in the 21 st century with a synopsis of the Assassin's Creed game so that from this relationship a conclusion can be drawn (23).

\section{RESULTS}

This study obtained 20 journals with a range of years from 2019-2021 and was strengthened by other sources in the form of an official website with a total of 2 sites, such as from the Assassin's Creed Official Website. The average source of journal articles is obtained from Google Scholar. In addition, the details of the number of journal articles based on the contents of the journal are as many as 9 journals containing the implementation of games for learning in the 21 st century and 11 journals regarding forms of history learning in the $21 \mathrm{st}$ century. While other internet sources are as many as 2 sites containing a synopsis of the Assassin's Creed game. The details of the number of journal articles based on the year of publication are 7 journals from 2019, 11 journals from 2020, and 2 journals from 2021, while 
other internet sources are 2 sites from 2019. Thus the total number references are 22 reviews in this article.

This study found several results. Starting from an explanation of history learning in the 21 st century, which at this time is experiencing rapid growth that can affect all areas of human life, especially the field of education. In the field of education itself, which has an important role, namely learning history, this is because history learning aims to produce students who have the ability to think critically, cooperate well, and can control feelings (10). Then it is explained about three historical learning competencies related to the changes that occur very rapidly at this time. Where from the three competencies it can be seen that history learning is very important to learn in the face of current technological developments (13). Furthermore, there is an explanation of the problem with current learning, where the current generation is starting to leave history lessons because they think that the lesson is boring so there needs to be a solution to overcome this problem. The solution is by looking at current technological developments, namely utilizing games as an alternative for students in understanding history lessons (19).

The next section describes the Assassin's Creed game. First, explain the profile of the game such as the year of release and publisher. Then followed by an explanation of several series owned by the Assassin's Creed game and their synopsis, each synopsis of the game has its own characteristics, especially the storyline and characters that match the facts of historical events (20-21). And finally, the relationship between the Assassin's Creed game and history learning is explained, the synopsis of this game has a role to make it easier for students and players to understand history lessons so that learning becomes an exciting and interesting lesson to learn. Thus, the presence of the Assassin's Creed game can be a solution to re-increase interest in learning history (18).

\section{DISCUSSION}

\section{A. Learning History in the $21^{\text {st }}$ Century Education}

In the $21^{\text {st }}$ century, there has been a technological development that is very influential in human life. This technological development has made it easy to access information that is not limited to space and time (4). One that affects human life is the field of education. In essence, education is an effort to increase the potential of students by providing supporting facilities in the teaching and learning process. Education must be able to adjust to this era of technological advancement so that it can produce students who can develop in this era to make this nation progress in the future (3). 
One education that needs to be considered is history learning. History learning is an important lesson to learn because it has a very important role in shaping the character of the nation through these students. In life in the 21 st century, there is a change from a previous life on a high scale and a wider dimension because thinking and innovation develop along with technological advances (13). Even so, history learning still pays special attention to the development of the quality of people who have thoughts in producing and using technology. According to some experts, education itself is related to the quality of humans in viewing, students in thinking, behaving using those inventions in the Fourth Technology Revolution era. Therefore, history learning needs to be developed in a life that has experienced this change to create students who can think critically, the ability to work together, and attitude skills. This is not only done in the school environment but can also be useful in socializing with families and communities (11).

To provide preparation for the younger generation in facing life in the 21 st century which is full of changes. There needs to be a development in history learning three historical learning competencies related to change, namely:

1. The ability to recognize and understand changes that have occurred, are happening, and will occur in the circle of one's own life, society, country, and humanity.

2. The ability to adapt to changes in enriching the lives of oneself, society, and the state as humans who use technology is not controlled by technology.

3. The ability to determine life changes in the future of himself, society, the nation, and mankind as the ruler of technology and the happiness of human life.

From the three competencies of learning history, it can be seen that history learning is certainly very important for students in following current technological developments. These three competencies need to be developed because they require the ability to think critically, creativity, communication, cooperation skills, and problem-solving (13). This means that when students learn to master competencies to understand and recognize change, they need the ability to think, cooperate, and control feelings (10). Thus when they learn to master these competencies, they can adapt and determine the changes that occur to them. In every learning activity, these competencies and abilities can be developed because a learning activity is wholeness in attitude, thinking, and acting (2).

History learning has four objectives, namely ways of thinking in history and historical skills, development to understand history, attitudes that are by one's own life as a citizen (patriotism and nationalism) (19). These four goals are related to each other which have a major role in producing quality young generations. History learning itself becomes a medium for 
developing the competence of students in the 21st century in the form of Historical Learning Competencies to develop these four goals to be more useful (13).

However, the current generation of learning history is starting to leave behind, because the rapid advancement of technology makes them lazy to study history. They think that history lessons are boring and always discuss the past so that the lesson is underestimated by many circles (10). History learning is very important to study because history itself has many useful meanings for everyday life. In history, we can know events that occurred in the past and we can imagine how an event occurred which is still remembered today. Historical learning also functions to determine a policy by looking at past events and can be used as learning so that the same incident does not occur in the future (14)(22). Not only that, but history study also teaches us to think critically the ability to work together, and the ability to control feelings. By having critical thinking we can know the meaning of an event in-depth, in addition to knowing the background we can understand the meaning and value that can be learned from the event (3).

Therefore, there is a need for a solution to improve the current generation, especially students, to be interested in learning history. Looking at the current situation where technology advances rapidly, we can take advantage of a game as a solution to learning history. This solution was taken because considering that in the 21 st century, the current generation has a high interest in games, but from games, they don't just play it but they can also take a value that is in the game. From the game, this can be used as an alternative for students to study history so that learning is not considered a boring lesson and after playing the game this they will be more curious about historical events in the game (7)(15)(17).

\section{B. Utilization of the game Assassin's Creed}

\section{Introduction to the game}

Based on the above explanation, we will use a game known as "Assassin's Creed" in the 21 st century. The game was released by Ubisoft on November 13, 2007. It tells the story of the battle between an assassin who fights for peace with free will and a Templar who wants to achieve peace under the rules. The series of works in this game feature the combination of art novels, historical novels and fictional characters with existing historical events and characters (20). Players used to use assassin characters, but now they can also play as Desmond Miles or Assassin Intimate to hunt down Templar targets. 


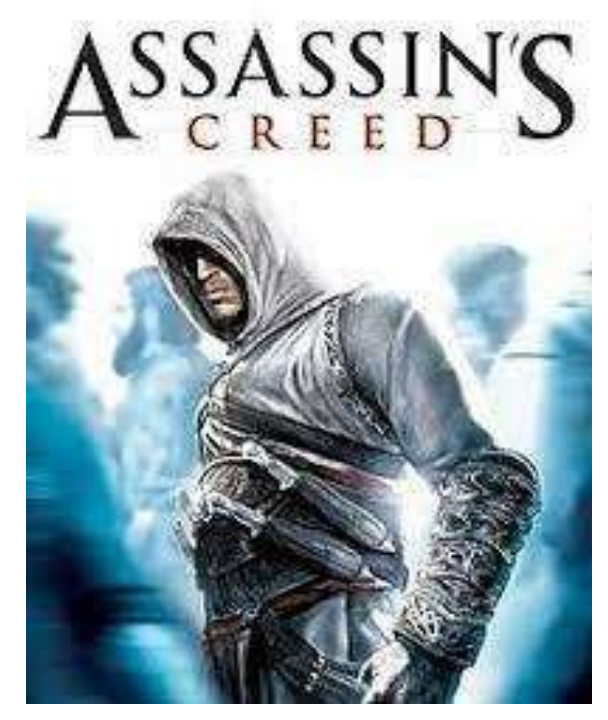

Assassin's Creed cover image

The main game of Assassin's Creed is set in an open world and completed from a thirdperson perspective. The protagonist uses his fighting skills to knock down opponents and use the environment to sneak. Players can freely explore the historical background while completing the main and side missions. In addition to single-player missions, some games also provide competitive and cooperative multiplayer gameplay. In addition, the main game was created for the console and desktop platforms, and a number of sub-games for the mobile, console, and handheld platforms were also released (16). This Assassin's Creed game focuses on the confrontation between two ancient secret societies - Assassins and Templars, as well as the indirect connection with past human civilizations. Throughout the game, it refers only to "the people who came before", where their gathering and much of the Earth's biosphere has disappeared due to the great solar storm that occurred thousands of years before the game started (8). The chronological order in the real world begins in 2012, but most of the stories in the game are based on historical events.

\section{How to play}

When playing the role of an Assassin, the game is usually played from a third-person perspective in an open-world environment, with a focus on sneaking and parkour. The game uses a mission structure to follow the main story, usually assigning the player to complete a public character assassination or secret mission. Apart from that, we can also do some additional missions, such as mapping the big city from the high poles, then "leap of faith" to 
the haystack below, collecting treasure all over the city, exploring cultural relics, and establishing a brotherhood of Assassins doing other tasks. or fund city reconstruction through purchases, in-store upgrades, and other features. Sometimes, players directly control Desmond. Desmond's trait is to use his passion to learn murderous techniques through the bloodshed effects and genetic abilities of the eagle's vision. Eagle Vision can distinguish friends, foes, and assassination targets by illuminating people of different colors. Through the Animus interface, players can try each mission that has been completed again. For example, in Assassin's Creed: Brotherhood, players can achieve better synchronization results by performing missions in certain ways (such as turning off-mission targets) (21).

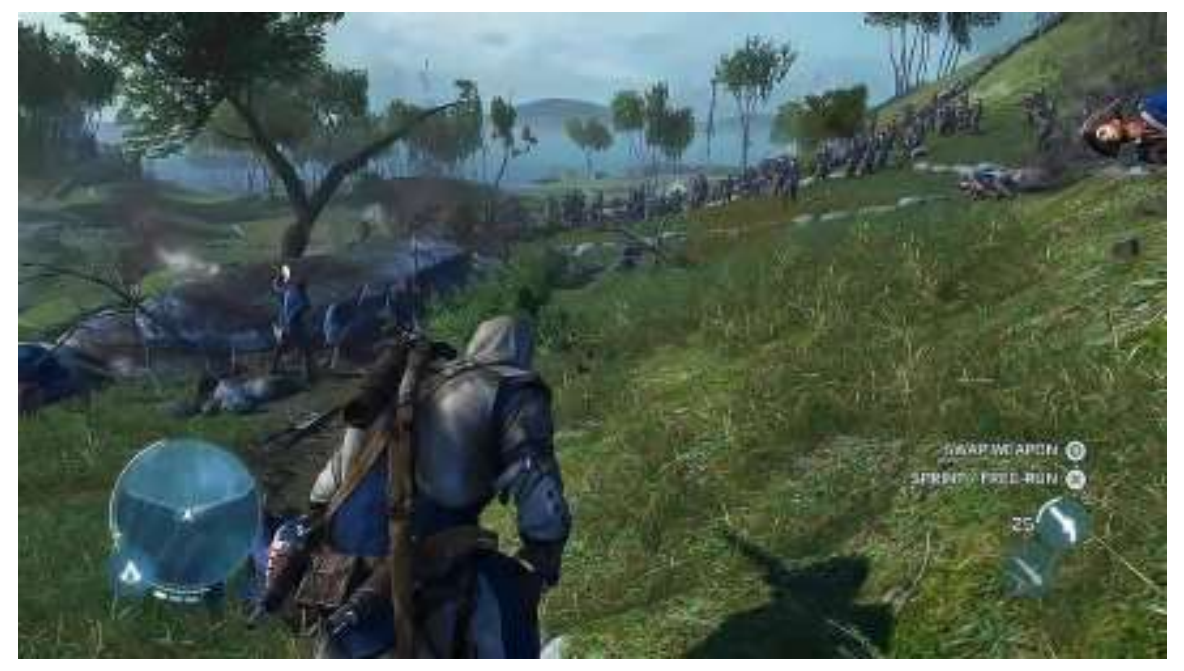

The gameplay of Assassin's Creed image

Use "active" and "passive" concepts and "active" concepts, such as running, climbing the sides of buildings, or jumping between rooftops, which are more likely to attract the attention of nearby defenders. When the guards become alert, the player must either attack them or turn away and find a hiding place, such as a haystack or well, and then wait for the guard's alertness to decrease. The combat system can use a variety of unique weapons, armor, and actions, including the use of a set of blades hidden in an assassin's armbands, and can also be used to kill targets covertly.

\section{Game Synopsis}

This game has a synopsis which is divided into several series with different story contents. The synopsis has a connection with historical events that have occurred, in the game, some figures are by historical facts so that this game is a recommendation for those who are interested in knowing world history. The series in this game is released every year with 
different story contents and more challenging missions, here are some series with a synopsis, namely:

1. Assassin's Creed I: Desmond Miles was kidnapped by Abstergo and forced to use a machine called Animus to explore the battle against Altair Ibn during the Third Crusade (1165-1257). -La'Ahad's memory. When Altaïr tried to prevent Robert de Sablé from taking the Piece of Eden, Altaïr broke the three principles of the Brotherhood of Assassins, and Desmond began to witness the incident. The leader of the Al Mualim Brotherhood reduced Altaïr to a rookie and ordered him to kill 9 Templar knights, including de Sablé, in order to restore his original status. Once, Altaïr's mission brought him face-to-face with de Sablé in front of Richard I of England, recalling De Sablé's conspiracy to assassinate the king. Creed of TheAssassin first introduced the core elements that will be maintained throughout the rest of the game series. The game creates a fictional historical version of Masyaf (seat of the Brotherhood), Damascus, Jerusalem, and Acre. It features several historical figures recorded in the story. Other core elements include the virtual Animus system, free running, climbing, stealth attack, parkour, and the pre-formulated combat system. The game requires players to complete several additional missions before they can obtain missions Assassin from local Brotherhood guides in each city, but in subsequent games, there are no prerequisites for using additional tasks.

2. Assassin's Creed II: In this series the story begins with Lucy returning and helping Desmond out of Abstergo, taking him to the assassin's vault, and talking to historian Shaun and technical support expert Rebecca (Rebecca) working together. Using an updated version of the Animus, Desmond watched Ezio Auditore da Firenze (14591524), a young aristocrat in Florence in the late 15th century, just before his father and two brothers. Before being executed for allegedly working for the Templars. Ezio and his mother and sister took refuge in the Monteriggioni villa of his uncle Mario Auditore, who helped Ezio become an assassin. Ezio and Mario learn that Rodrigo Borgia is the leader of several Templars, all of whom are responsible for the execution of their family, and with the help of their friend Leonardo Da Vinci, he methodically kills several low-ranking Templars and learns that Borgia has captured the Piece of Eden. , which is called the Apple of Eden. As in the first game series, Assassin's Creed II is set in Florence, Venice, Forli, Toscana, and the San Gigmano area and relates to events that occurred at that time as the storyline of this series. The missions are divided into 
the main story, which is about a memory mission that describes the events that occurred in Enzo's life, and additional missions that can be completed at any time. Then the mission structure itself is maintained in other games in the series.

3. Assassin's Creed: Brotherhood: The story began with Desmond and his friends, who avoided the ruins of the Monteriggioni villa, Desmond re-entered the Animus and continued Ezio's memory, Especially to determine the location of the Apple of Eden. After facing Rodrigo Borgia, Ezio returned to Monteriggioni, but Rodrigo's son Cesare Borgia attacked them. Mario (Ezio's uncle) is killed and the Apple of Eden is found. Ezio promised to retaliate by helping the Romans get rid of the influence of the Borgia family. When Ezio secretly turned the townsfolk into opponents of the Borgia family, he gained followers who wanted to join his cause, and Ezio trained them as assassins. In order to kill Cesare and Rodrigo in Castel Sant'Angelo, Ezio witnessed Cesare forcing his father to eat it, preparing to kill his son with a poisoned apple. Ezio hunted down Cesare, and finally, Ezio managed to catch him and retake the Apple of Eden.

4. Assassin's Creed Revelation: In the Animus computerized "core", subject 16 (Clay Kaczmarek) explains to a comatose Desmond that his mind must be completely synchronized with Altaïr and Ezio, otherwise he will fall into a state of dementia. Desmond looked at Ezio's memory, which began to develop only a few years after the start of the story Brotherhood. Ezio studied the history of the Assassins and then went to Masyaf to find the location of the Altaïr Library, which was rumored to have great power. The Templars also tried to open the library, but it could only be opened with five keys scattered throughout the Ottoman Empire's Constantinople. Ezio learns that the city of Constantinople is in a dispute between Selim and Ahmet over the position of Sultan. Ezio was assisted by Sofia Sartor; where both fell in love. Ahmet was later found as a Templar and killed by Selim after fighting Ezio. Ezio uses the keys obtained to witness Al Mualim's memories before and after his death, which show the death of Al Mualim's wife and youngest child in the murderous coup. Altaïr spent twenty years in exile before returning to Masyaf to kill usurpers and regain power. Altaïr described his memory in the lock and asked his friend Niccolò Polo to hide it. Later, Ezio and Sofia go to Masyaf and open the library to find the bodies of Altair and Piet of Eden. Ezio is assisted by Sofia Sartor; both fell in love. Ahmet was later found to be a Templar, and killed by Selim after fighting Ezio. 
5. Assassin's Creed III: This story begins with an attempt to stop the end of time that was told in the previous series, then Desmond and his friends entered a place in the form of a cave on October 31, 2012, and used Apple of Eden to open the door and find a large room. Its predecessors used technology, including other doors requiring locks. Desmond suddenly falls into a wandering state and is placed in the Animus to commemorate his ancestry on the American continent. This time, Desmond enters the memory of Haytham Kenway, who is later discovered to be a Templar agent from England. Templar Charles Lee won the trust of Mohawk together because they wanted to find the location of the temple, but unfortunately, they were unable to open the temple with a medal. Then, the in-game story turns to Haytham's son, Ratonhnhaké: ton. As a child, he witnessed Li and his troops attacking his village and killing his mother (21).

\section{Implementation to Learning History}

From the explanation of the synopsis above, of course, the contents of the story are related to historical events. The storyline explains the history that occurred in different parts of the world, but in this game, the setting is replaced by some fictional ones. Although some of the settings are made in fiction, the events that occur in each series have their meaning and are related to historical facts (7). In addition to the setting, there are characters in each series in this game who have similarities to figures in historical events, for example in the Assassin's Creed III series which tells the events of the American revolution wherein the story there are important figures involved in the event such as George. Washington. Thus, this game has benefits for players and students alike to understand history lessons because in this game they are not only playing but they are also learning about the events that occurred in the game (9).

Seeing the rapid development of technology, it is necessary to develop a method to improve history learning, such as the game Assassin's Creed. This game is highly recommended for players and students who are interested in learning history so that it makes history learning not boring. This game is divided into several series that can be played by players with different synopses, then each series has unique characteristics that make the game fun for those who play it. This game has been played by millions of players around the world, so there is no doubt about its quality because this game also has good image quality and storyline, so those who play it will not feel bored completing all the missions in the game (22). 


\section{CONCLUSION}

History is a science that is very important to learn for human life, where learning history itself has a role in shaping the character of each student to face this era of globalization which is experiencing rapid development. History learning has 3 main competencies, namely: the ability to think, the ability to cooperate, and the ability to control feelings, these three things have a role in dealing with changes that are happening today. Judging from these competencies, it is necessary to further develop historical learning in the 21 st century to create a young generation of character and quality. However, the current generation is starting to leave history learning because they think history is a boring lesson and always discuss past events. Even though studying history is very important because knowing the past can make a lesson for the future, so there is a need for a solution so that student's interest in learning history can increase again.

Seeing these problems, by taking advantage of technological advances we can use games as a medium to increase interest in learning history. The game used in Assassin's Creed, the game tells about the struggle of an Assassin in achieving peace with different backgrounds. This game consists of several series with different synopses and settings that make this game interesting to play. The synopsis contained in this game has links to historical events that have occurred, besides that there are also figures who are important in historical events such as George Washington. Thus, this game is highly recommended for players and students who want to know the history of various worlds with quality images and interesting storylines so that this game is not boring to use. Therefore, this article is very useful in providing information about the use of the Assassin's Creed game as a solution to increase interest in learning history at this time.

\section{REFERENCES:}

1. Arta A, Putri D. Game Edukasi Pembelajaran Sejarah Berdirinya Indonesia Untuk Sekolah Dasar. J Tek Elektro. 2020;2(20):77-81.

2. Arshad M. Tantangan Manajemen Pendidikan Islam, Hukum Islam dan Bahasa Melayu di Era Revolusi 4.0. In: Prosiding Seminar Internasional dalam Rangka Kegiatan Studi Visit 2019. 2019. p. 117.

3. Desrina \& M. Penguatan Pendidikan Karakter \& Pembelajaran Abad 21. Pros Semin Nas Pendidik PPs. 2020;2(1):999-1015.

4. Indahsari H, Sari Y. Pengembangan Pendidikan Kreatif Dengan Memanfaatkan Pembelajaran Digital. In: Prosiding Seminar Nasional Pendidikan Program Pascasarjana Universitas PGRI Palembang. 2020. p. 293-306.

5. Kaviza M. Pembelajaran Berasaskan Bahan dalam Mata Pelajaran Sejarah. Malaysian J Soc Sci Humanit. 2020;5(5):149-56.

6. Kurniawan H. Infografik Sejarah Dalam Media Sosial: Tren Pendidikan Sejarah Publik. Sej dan Budaya [Internet]. 2020;14(2):1-13. Available from: 
http://journal2.um.ac.id/index.php/sejarah-dan-budaya/article/view/13934/6957

7. Mulyani S. Implementasi Game Edukasi Dalam Pembelajaran. J Teknol Inf. 2020;1(2):5672.

8. Pangau L, Kaunang S, Lumenta A. Game Based Education : Pengenalan Peristiwa Sejarah Permesta di Minahasa. J Tek Inform. 2019;14(2):203-8.

9. Pratama L, Bahaudin A, Lestari W. Game Edukasi: Apakah membuat belajar lebih menarik? 2020;(Universitas Negeri Yogyakarta).

10. Prayogi RD, Estetika R. Kecakapan abad 21 : kompetensi digital pendidik masa depan. J Manaj Pendidik. 2019;14(2):144-51.

11. Reflianto, Syamsuar. Pendidikan dan Tantangan Pembelajaran Berbasis Teknologi Informasi di Era Revolusi Industri 4.0. J Ilm Teknol Pendidik. 2019;6(2):1-13.

12. Rifai A, Harli E, Nulhakim AL, Raya J, No T, Gedong K, et al. Perancangan Aplikasi Edukasi Sejarah Peradaban Tertua Berbasis Android Di Smkn 10 Bekasi. 2021;1086-92.

13. Hasan S. Pendidikan Sejarah untuk Kehidupan Abad Ke 21. Hist J Pendidik dan Peneliti Sej. 2019;II(2):61-72.

14. Basri I, Hastuti H, Sejarah J, Ilmu F, Universitas S, Padang N. Bagaimana Sejarah Seharusnya Diajarkan? ( Sebuah Kajian Pemikiran Pembelajaran Sejarah ). 2020;2(4):140-8.

15. Azahari I. Pengembangan Media Pembelajaran Cursor Game Pada Mata Pelajaran Sejarah Kelas X. Skripsi Progr Stud Pendidik Sej Jur. 2020;21.

16. Ningrum S, Maslan A. Aplikasi Trivia Game Mata Pelajaran Sejarah Berbasis. Khazanah Ilmu Berazam. 2020;3(2):327-36.

17. Suarmini M. Metode Gamifikasi Berbasis Tri Hita Karana Sebagai Alternatif Pembelajaran Abad 21. Maha Widya Buwana. 2019;2:42-7.

18. Novayani W. Game genre untuk permainan pembelajaran sejarah berdasarkan kebutuhan pedagogi dan learning content. J Komput Terap [Internet]. 2019;5(2):54-63. Available from: https://jurnal.pcr.ac.id/index.php/jkt/

19. Zaenal M, Anis A, Mardiani F. Memperkuat Identitas Nasional Melalui Model Pembelajaran Berpikir Historis ( Mpbh ) : Antara Nyata Atau Sebuah Asa ? 2021;6(3).

20. Ubisoft. Assassins Creed Symphony Tour 2019. 2019; Available from: https://news.ubisoft.com/en-us/article/7bZoF8hekrqr183IhzOY0f/assassins-creedsymphony-tour-begins-2019

21. Fogel S. 'Assassin's Creed' Symphony Trailer Highlights Holographic Characters. 2019; Available from: https://variety.com/2019/gaming/news/assassins-creed-symphony-trailer$1203184414 /$

22. Afwan B, Suryani N, Ardianto DT. Analisis Kebutuhan Pembelajaran Sejarah Di Era Digital. Proceding Literasi Dalam Pendidik di Era Digit Untuk Gener Milen. 2020;9.

23. Sidiq U, Choiri MM. Metode Penelitian Kualitatif di Bidang Pendidikan. Ponorogo: CV. Nata Karya; 2019.

24. Zed M. Metode Penelitian Kepustakaan. Jakarta: Yayasan Obor Indonesia; 2008.

25. Ketut Sudarsana, I., Putu, I., Putra, A. W., Anam, F., Istianti, T., Glorino, M., Pandin, R., Bhawika, G. W., Listiawan, T., Saddhono, K., Abdullah, D., Cathrin, S., Hadjri, M. I., \& Laili, R. N. (2019). To cite this article: I Ketut Sudarsana et al. Society, and Technology Journal of Physics: Conference Series, 1363, 12062. https://doi.org/10.1088/17426596/1363/1/012062

26. Rahim, R., Kurniasih, N., Gs, A. D., Saddhono, K., Riasti, B. K., Rangka, I. B., Kurniawan, D. E., Putera Permana, E., Anam, F., Listiawan, T., Glorino, M., Pandin, R., Gumono, G., Astuty, N., 12, Y. B., Eka, D., Wardhana, C., Mustika, W. P., \& Rindawati, S. (2019). Random and match game for education purposes with model learning technology system architecture. 12038. https://doi.org/10.1088/1742-6596/1179/1/012038 